\title{
The Effect of Work Plateau on Intention to Remain: Mediating Role of Organizational Commitment
}

\author{
Ahmad Latifian
}

\begin{abstract}
In the present study, the the impact of work plateau on intention to remain at work with the mediating role of organizational commitment has been studied. The statistical population of this research is all employees of Ferdowsi University of Mashhad. The research method is descriptive-survey. According to statistics of personnel management office, the number of employees is 1100 in 2017. In order to determine the sample size, due to the limited population, Morgan table was used and 285 people were selected from population through random sampling. In order to collect the data, Alan and Meyer (1990) questionnaire was used to assess organizational commitment, a researcher-made questionnaire was used to investigate the intention to remain at job and Miliaman's questionnaire (1992) was used to investigate career plateauing. The validity of these three questionnaires has been confirmed by experts. Reliability of the questionnaire is confirmed by Cronbach's alpha coefficient of $86 \%, 91 \%$ and $84 \%$, respectively. The statistical methods used in this research to test the hypotheses are $T$ value and structural equation modeling. Structural equation model in this study was determined using Liserl software, according to which the content plateau and structural plateau, considering the mediator role of organizational commitment, has a negative and significant impact on employees' intention to remain at work.
\end{abstract}

Keywords: Career Plateauing, Remain at Work, Organizational Commitment.

\section{INTRODUCTION}

Global rapid development in science, technology, industry, and management has led many of the world's leading companies to apply creativity and innovation in their goals, attitudes and interests. With all the positive consequences, this matter has changed the organization's structure in a fundamental way. Most organizations, with the creation of professional teams and the transfer of tasks to operational levels, seek to minimize and reduce managerial levels. Although these developments help the organization's agility and effectiveness, shortening the stages of progress and the movement of structures toward flattening has led to job plateau in employees, a phenomenon that is expanding at a fast pace (Salami, 2010, Jung \& Tak, 2008). Accordingly, if employees realize that promotion and progress in job path is inaccessible, they will find this progress in other organizations and consequently the desire to leave the organization will increase (Lee, 2003, p.539).

Fayol also believes that in order to be able to maintain the

Revised Manuscript Received on July 22, 2019.

Dr. Ahmad Latifian, Assistant professor, Department of Management, Ferdowsi University of Mashhad, Mashhad, Iran experienced staff in organization, they should be managed in order not to abandon the organization. Surely, paying attention to welfare and motivational issues and providing staff growth opportunities and etc., is of the most important reasons for employees' commitment to the organization. If they are not taken into account, employees will not be accountable to the management and organization and leave them very quickly. On this basis, it is very important to maintain the staff and prevent them from leaving the organization.

\subsection{Work Plateau}

The point of employees' career path, where vertical appointment or upgrading is not possible in near future, is called Work Plateau (Lee, 2003). One of the main reasons for work plateau is factors such as supervision, number of employees, job conditions, job expertise, success in the past years, salaries, benefits, job problems, organizational support and organization size. Additionally, individual factors such as age, gender, social status, education, number of children and family responsibilities are among the main reasons for work plateau (Hurst, Kungu \& Flott, 2012). In fact, employees who experience work plateau, think that employers have relinquished their jobs (Penkar D J \& Agrawal, 2012). Anderson believed that the stages of human resource development and growth include intuition, inspiration, insight, hard work and continuous learning. Once the cycle is stopped, people are approaching work plateau (Khanifar, 2006). Bardwick (1986) believes that there should be a distinction between two types of work plateau. $\mathrm{He}$ considers these two factors as follows:

- Structural factors: This factor is related to the structure of the organization and the promotion of the job. He believes that, for example, of one hundred people hired according to their merits, only one person reaches the middle or excellent management level of the organization. The rest of the employees are at lower levels and, despite the competencies they have gained, they are not able to climb. Therefore, when employees do not witness any certain path for success and do not see any progress among their colleagues, they experience work plateau (Khanifar, 2006, 12-20 / 19-20).

- Content factors: Sometimes people experience work plateau due to their occupational content. Typically, jobs with low diversity and tedious content fall into this category. They have been doing a certain task for many years and know exactly what is expected from them every day and there's nothing new for learning.

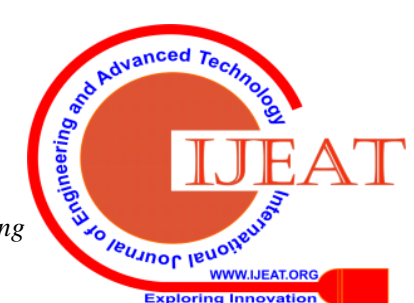


In other words, employees know everything they need to know and there is no chance to learn more. In fact, content plateau occurs when a person is completely mastered by the job and no longer has the opportunity to learn more (Jung \& Tak, 2008, 189). Content dimension can include all organizations. Even academies and universities are not exception.

Plateauing in job content is reflection of the lack of diversity and the challenge in job, which means doing a routine and boring job, not an exciting and challenging one. This phenomenon will be more costly for the organization to achieve its goals (Armstrong, Stassen \& Stassen, 2013).

Lee defined job plateau based on duration of occupation. Accordingly, job occupation for five years and lack of progression thereafter represents plateau, while, according to most researchers, job occupation for 3 to 5 years is considered plateau (Milles et al., 2013).

The range of employees' response to plateau is largely fluctuating between high and dynamic performance and positive attitude to limitless dissatisfaction and poor performance (Taleghani and Mottaghi, 2002). Barwick (1986) assumes that employees, who have experienced plateau, pass two stages of resistance and resignation. During the resistance phase, they maintain the hope of gaining promotion and continue to judge their progress according to time horizons. The result is that they maintain their commitment to the organization and adapt their plateauing situation. But as soon as they recognize that there will be no promotion for them, they will enter resignation stage so they gradually quite the job and become inactive during this stage.

Factors that make up the morale of plateau in career path include lack of compliance with job description due to inappropriate selection system (and lack of intrinsic motivation in job), lack of attention to proper job design, lack of independence and job feedback.

In addition, factors that lead to work plateau in early years of starting the job are as follows:

Internal factors experience and plateau are still evolving.

- Lack of flexibility in considering options

External factors

- The pressures of inequality in society

- Increasing competition in popular jobs or working in smaller job sectors.

Extensive integration, restructuring, downsizing, slow upgrading, and ultimately decreasing organizational posts that strictly limits opportunity to progress vertically, is often referred to work plateau in career path (Foster et al., 2004).

Hornady believed that reconciling individual beliefs with career path on a regular basis would be a great help in removing the signs of work plateau (Hornady, Ann. 1995, p. 33). Accordingly, individual and organizational factors include lack of appropriate organizational benefits. Thus, organizational factors include non-compliance with job description, specific type of customers and adherence of managers to the organizational climate in the appointment process and fear of lack of alternatives in the event of
- Lack of transparency in individual demands, as job

displacement of employees, lack of skill and motivation for progress; and individual factors include lack of learning new knowledge, personal problems, lack of hope for promotion in organization and comparison with others (Kolahchiyan and Rahmatinia, 2017).

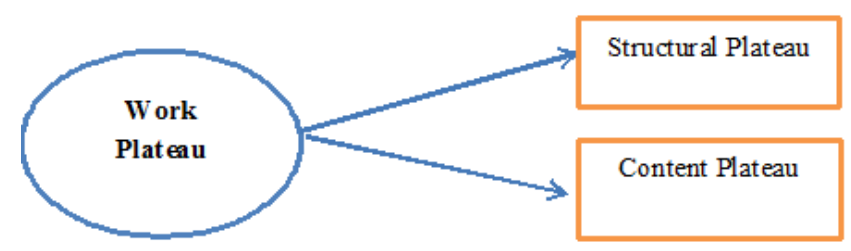

Figure No. 1 Job plateauing Components

\subsection{Organizational Commitment:}

It is important to pay attention to employees' needs, as in this case they will have commitment toward organization. Organizational commitment predicts the stability of the workforce and the amount of displacement. Organizational commitment also shows the extent to which an organization can count on employees' participation in its activities and its growth, beside it, organizational commitment is an indispensable factor for quality of work life (Ketchum and Trist 1992, quoted by Morin, 2008).

Organizational commitment is the relative power of recognition and participation in a particular organization, distinguished by at least three factors of strong belief and acceptance of the goals and values of the organization, the intention to make significant efforts on the basis of the organization and the strong desire to continue membership in the organization (Meyer, Alan and Smith, 1993).

Meyer et al. (1990) have provided three dimensions for assessing organizational commitment:

- Affective commitment is the emotional attachment of employees to the organization, so that they represent their identification with it and engage in organization activities. In fact, employees with high emotional commitment remain in the organization, accept its goals and in order to achieve those goals, display excessive efforts or even show great self-sacrifices (Haj Karimi, Tabarsa and Rahimi, 2008).

- Normative commitment emphasizes the sense of being required to stay in the organization; and those with strong normative commitment feel that it is their duty to stay in the organization (Haj Karimi, Tabarsa and Rahimi, 2008)

- Continuance commitment refers the level of investment of individuals in their organization (Alan \& Meyer, 1990; Balay, 2000; Cotten, 2004). This theory claims that as long as individuals remain employed by an organization for a long time, they accumulate investments and reserves, so as long as this time is prolonged, leaving organization will be more costly.

These investments and reserves include time, work, organizational skills, and high costs case of leaving organization that discourages them from looking for other jobs and friendly relations in workplace because of the nature of this kind of commitment (Cheng and Stockdale, 2003). 
In summary, in this type of commitment, individuals stay in the organization because they need to stay (Kuvaas, 2003).

Figure 2 shows the factors that affect the commitment and results of organizational commitment (Moghimi, 1996).

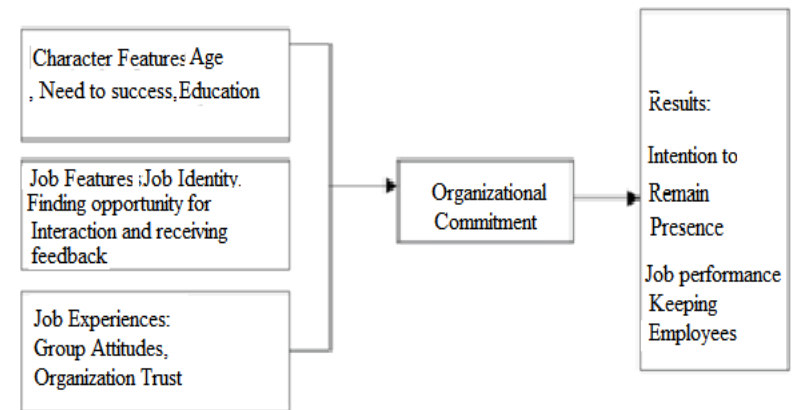

Figure No. 2: factors that affect organizational commitment and their results

Based on this figure, commitment that results from the characteristics of a job, personality, and work experience is effects on factors such as intention to remain in the organization.

O'Reilly and chatment (1986) defines organizational commitment as the supportive and emotional attachment to the goals and values of an organization, for the sake of organization and being way from its instrumental values. The criterion of commitment is the intention of individuals to offer their energy and loyalty to the social system (Kantar, DS, 1980). Committed employees are more disciplined in their work and work longer in the organization.

Therefore, managers should maintain the commitment and dependence of employees to the organization (Griffin, 1998: 126). Organizations that have members with high levels of organizational commitment have higher performance and less absenteeism, delay and displacement (Molayi, 2006: 20). In fact, organizational commitment as an attitude predicts leaving the organization better than other work attitudes, especially job satisfaction (Bhatnagar, 2005, p. 419).

The interest in organizational commitment is largely due to its negative relationship with leaving the organization. More committed employees leave the organization less compared to those who are not committed. That is, there is an inverse relationship between employees' organizational commitment and absenteeism and plateau (Egan, Yang, \& Bartlett, 2004). It can be said that recognition and maintenance of human resources is not just keeping people in the organization, but connecting them to the organization and creating interdependence between the individual and the organization. As there are employees who have been in the organization for years, but they are compelled to remain, and in this case they will not only help the organization, but also if they find any opportunity, they will place heavy burdens on the organization. Therefore, in order to increase the commitment of employees, it is necessary to pay attention to their needs (Delgoshayi etal, 2008).

Decenzo and Robbins define human resource management as a process that involves four tasks of attracting, developing, motivating and retaining human resources. Therefore, defining of human resources maintenance programs is one of the tasks of human resource management, which is

implemented with two concepts for the maintenance of employees. One is to maintain employees with the concept of implementing safety and health programs that are implemented to ensure the health of the staff, and the other is to maintain employees with the concept of welfare programs and pay benefits to prevent employees from leaving (Gaffney, S., 2005).

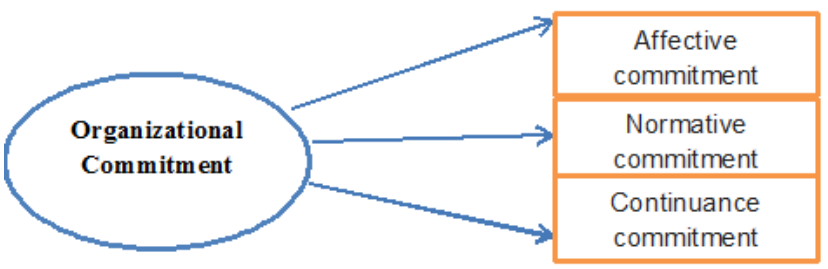

Figure No. 3: Organizational Commitment Components

\subsection{The desire to remain at work in organization:}

The desire to remain refers to the wishes and interests of employees to be members of the organization (Balfour et al., 1996), as one of the important goals of organizations is the maintenance of employees (Stumps, 1997). The desire to remain in organization is employees' desire to continue their job with the motivation of organization membership and the desire for more effort and continuity of cooperation (Currivan, 2000, Evans, 1988, Muller 13, 1994). Having such an expert and loyal employees that are consistent with values and goals of organization, have strong motivation and are committed to maintaining organizational membership, is of the basic and essential needs of any organization, because the organization requires staff to go beyond the job descriptions of their routine tasks. The presence of such forces in each organization, while reducing absenteeism, delay, and displacement, will significantly increase the organization's performance; enhance employee spiritual joy and leads to better manifestation of organizational transcendental goals and individual goals achievement. Lack of commitment at low level leads to negative outcomes for employees and organization: such as leaving the organization, increasing absenteeism, reluctance to stay in the organization, reducing customer confidence and reducing revenue.

Evidence suggests that dissatisfied employees leave their organization and resign more, as they expect the organization to provide opportunities for learning, because these opportunities are useful and effective for their professional development and recruitment in the future (Stephen Robbins, 1994). The results of the recent study show that at least $40 \%$ of the employees were looking for new job opportunities due to dissatisfaction with the promotion path and many of them have left their current organizations as soon as finding better opportunities (Conner, 2014, p. 198). Gholipour et al. (2003) in their research showed that the factors affecting employee's intention to remain include environmental, personal, structural, organizational commitment and job satisfaction factors, which questions of the questionnaire were designed based on it. 


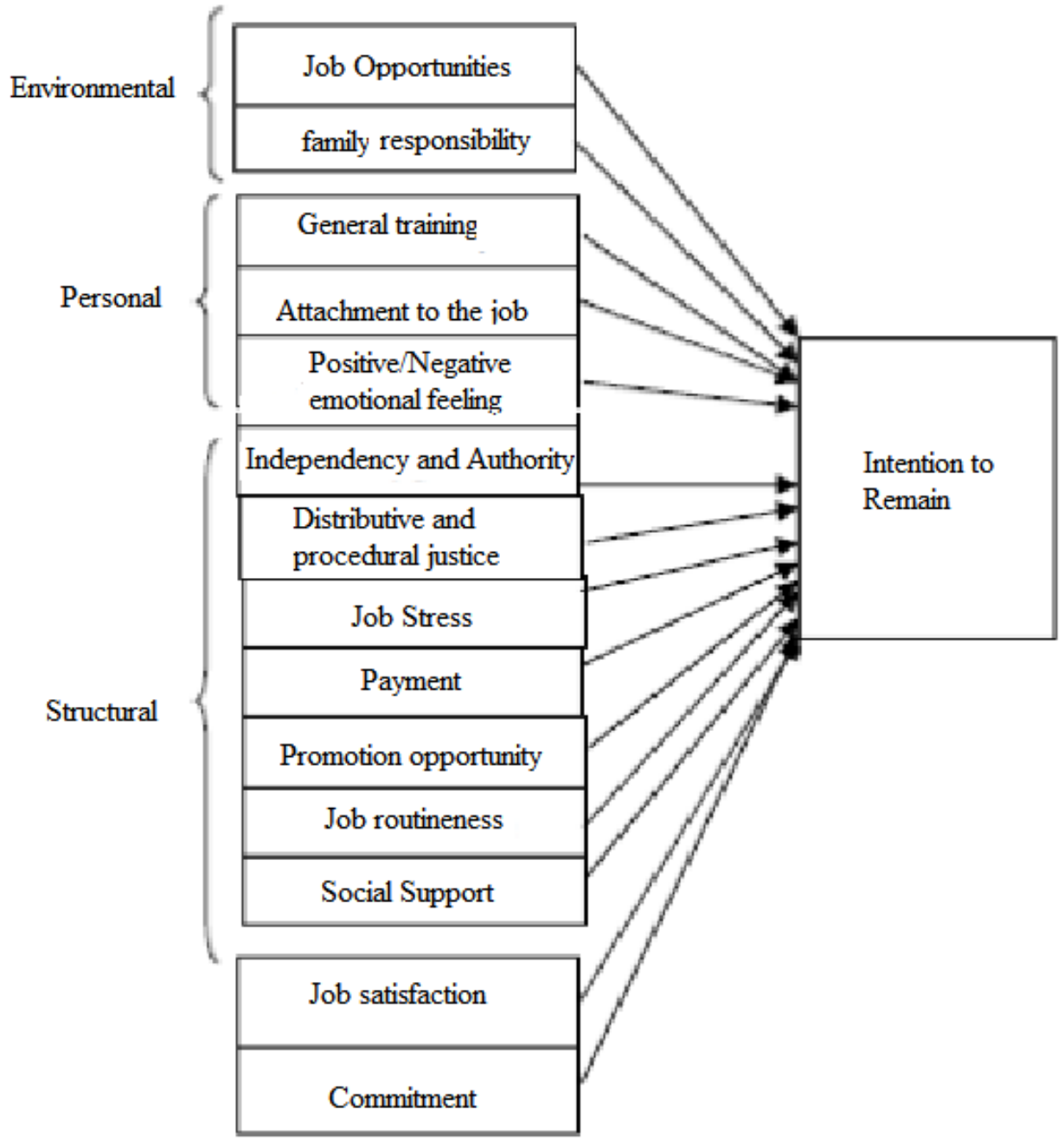

Figure No. 4: Components of desire to remain at job

\section{CONCEPTUAL MODEL OF RESEARCH}

Regarding the subject of the research, namely, "Investigating the effect of work plateau on desire to remain in organization with mediating role of organizational commitment", in this model, the components of work plateau in Milliamen's pattern
(1992), the dimensions of the tendency to remain in the pattern of Gholipour (2003) as well as organizational commitment components of Allen \& Meyer (1990) pattern were used.

The conceptual model of research is shown in the figure below.

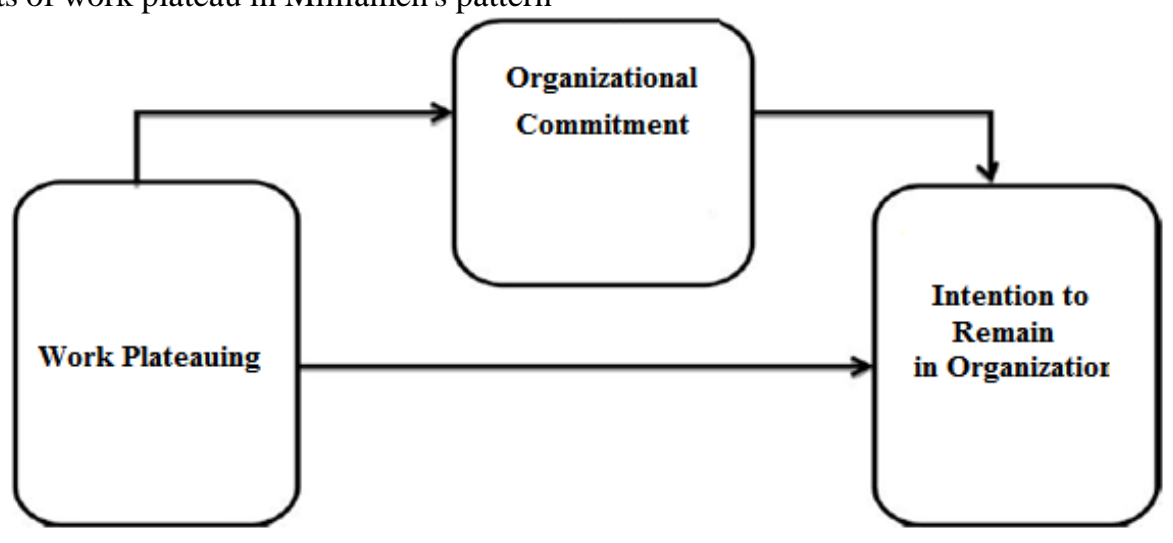

Figure No. 5: Conceptual Model of Research 
In the conceptual model of this research, it has been assumed that work plateau, in addition to having a direct and negative effect on the desire to remain in organization, also affects organizational commitment. Despite the positive and significant impact of organizational commitment on the desire to remain in organization, work plateau has a negative effect on commitment, which has reduced the desire to remain in organization.

\section{LITERATURE REVIEW}

According to researches, work plateau has negative relationship with positive attitudes such as job satisfaction and organizational commitment (Choy \& Savery, 1998; McCleese, Eby, Scharlau, \& Hoffman, 2007; Nachbagauer \& Riedl, 2002; Salami, 2010; Jung \& Tak, 20081; Drucker-Godard, Fouque, Gollety, \& Le Flanchec, 2014). Also, there is a positive and significant relation between work plateau and negative attitudes such as intention to leave the organization (Ongori, \& Agolla, 2009; Sharifian, Pirayesh \& Rahimi, 2013; Heilmann, Holt \& Rilovick, 2008; Lee, 1999; Klehe, Zikic, Van Vianen \& De Pater, 2011; Lentz and Allen, 2009; Choudhary, Ramzan \& Riaz, 2013). In his study, Hillman (2008) found that the perceived work plateau has a significant and positive relationship with the desire to leave the organization (Heilunarun, Holt \& Rilovick, 2008). Fayyazi \& Ziyaee (2014) in a research entitled "The study of the effect of work plateau on job burnout and the desire to quit among librarians" concluded that the degree of work plateau, job burnout, and intention to leave the organization among librarians is more than average, and perceived work plateau has a significant effect on job abandonment and burnout; in other words, librarians who have perceived more work plateau, report more burnout and intention to leave the organization. In a study, Slokum and Crohn (1987) observed that employees, who experienced work plateau, offered different reasons for leaving the organization compared to others. Generally speaking, people with no work plateau, mentioned lack of higher salary or benefits, or new opportunities for higher responsibilities as the reasons for leaving the job; however, people experienced work plateau, mentioned organization policies, reorganization and personal matters such as health problems, as the reason to leave the job (Baoguo, 2015, 324). Studies have shown that employees who progress in organization in a good job path are more motivated, have more roles and beyond the role performance, are more satisfied and report less absenteeism and burnout. For this reason, organizations are always looking for effective solutions to manage employee career paths (Rotondo \& Perewe, 2000). It is worth mentioning that, based on related literature; the greatest effect of work plateau is employees' intention to leave the job (Ongori and Angolla, 2009; Price and Muller, 1981; Bluedorn, 1982; Miles, Gordon, Storlie, 2013; Heilmann, Hot, Rilovick, 2008; Foster, Shastri, Withane, 2004). In general, when employees voluntarily decide to leave the organization, (Griffeth, Steel, Allen, Bryan, 2005) the effectiveness of that organization is reduced for various reasons. At first, when employees leave, the organization loses knowledge of its employees. Secondly, the organization needs a lot of time and money to replace human resources. Third, it is necessary to allocate sufficient time and money for the training of the replaced human resources. Therefore, it is very important to pay attention to the reasons for employees' intention to leave the job. Saleh Ardestani and Seyed-Naghavi (2006) in their research entitled "Explaining the Relationship between Work Plateau and Organizational Indifference and the Desire to Quit among Employees in Iran's Insurance Employees" concluded that the work plateau have a positive and significant relationship with organizational indifference and intention to leave the job. Rotondo \& Perewe (2000) investigated the relationships between work plateau prevention behaviors and its organizational consequences for employees. The results of their research indicated that one of the most important consequences of work plateau is burnout and abandonment of the organization. According to researches, work plateau has a negative correlation with attachment and commitment to work (McCleese et al., 2007, 284; Salami, 2010, 501; Drukker et al., 2014). Accordingly, it can be said that stagnation and lack of progress in rganization reduce the organizational commitment of employees and also reduce the attachment of employees to their jobs. Tabarsa et al. (2014) designed and explained a plan for management of work plateau in Ministry of Industry, Mine and Trade. The results obtained from the study of relationships in the final model of research showed that although content plateau doesn't directly predict the consequences of the study, but it can affect the work outcome by influencing on other types of plateau. In general, estimates in the final model of this study showed that $34 \%$ of job satisfaction variance, $24 \%$ of psychological deprivation, $43 \%$ of tendency to quit the organization and $34 \%$ of organizational commitment can be explained by the dimensions of work plateau.

Some researchers have considered the relationship between work plateau and organizational commitment. Findings in Jang and Tak's research (Jung \& Tak, 2008), Salami (Salami, 2010), Lentz and Allen (Lentz and Allen, 2009) and McCleese and Ebay (McCleese \& Eby, 2006) indicate that work plateau has negative relationship with organizational commitment and its dimensions, including affective commitment.

Salami (2010) also showed that work plateau is correlated with job satisfaction and organizational commitment. Balfour and Wechsler (1996) also found a positive and direct relationship between three dimensions of organizational commitment and desire to remain in organization. Meyer et al. (2002) reported a positive relationship between organizational commitment and desire to remain in organization. According to Mafi's research about professional staff in organization of investment and technical assistance, when the high level of affective and normative commitment of employees is high, there is a tendency to stay in organization, but this is not related to continuance commitment. A study by Powell and Meyer (2004) among more than 200 staff at a university showed that continuance and affective commitment had a negative effect on the tendency to relocate. The meta-analytic study by Meyer et al. (2002) on more than 150 research papers published in the form of published and unpublished papers and academic dissertations during the years 1985-2000 in the United States showed that all three types of commitment had a negative relationship with displacement and the desire to 
leave the job. A study by Simons (2005) among 317 employees of a therapy center showed that there is a slight relationship between organizational commitment and relocation. Committed employees are less likely to change their job and are likely to have a higher level of performance (Stup, 2006).

\section{RESEARCH HYPOTHESES}

1. Work plateau has a negative impact on the intention of employees to remain in organization

2. Work plateau has a negative impact on organizational commitment

3. Organizational commitment has a positive impact on employees' intention to remain in organization

\section{RESEARCH METHOD}

The purpose of this study is applied and its method is descriptive-survey. The causal relationship between the variables in the research has been analyzed using the structural equation modeling by the help of LISREL software. Structural equations modeling consists of two parts named measurement model and structural model; and the model variables are classified into two groups of latent variables and observed variables (Klein, 2010). The statistical population consists of all employees of Ferdowsi University of Mashhad. Using a random sampling method and Morgan table, 285 people were selected. The data collection tools included three questionnaires:

1) Alan and Meyer (1990) questionnaire was used to assess organizational commitment that has 20 questions and measures three dimensions of affective, continuance and normative commitment by five-point Likert scale. Its content validity is confirmed by experts and its reliability is confirmed by Cronbach's Alpha method that is $86 \%$.
2) A researcher-made questionnaire was used to investigate the intention to remain that has 20 questions and measures five dimensions of environmental, personal, structural, and organizational commitment and job satisfaction factors by five-point Likert scale. Its content validity is confirmed by experts and its reliability is confirmed by Cronbach's Alpha method that is $91 \%$.

3) Miliaman's questionnaire (1992) was designed to examine career plateauing with 20 questions that measures two dimensions of structural and content plateauing by five-point Likert scale. Its content validity is confirmed by experts and its reliability is confirmed by Cronbach's Alpha method that is $84 \%$.

\section{SAMPLING}

The statistical population of the present study consists of employees of Ferdowsi University of Mashhad, whose number is 1100 in 2017. According to Morgan sampling table, the sample size estimated 285 people. Sampling method in this research is simple random sampling based on random numbers table.

\section{RESULTS}

\section{1 demographic characteristics of respondents}

The demographic characteristics of the sample are shown in table 1 . As can be seen, the highest frequency of respondents' age is $54 \%$ and belongs to the age range of 46 to 55 years, and its lowest value belongs to the range of less than 25 years, with frequency of $3 \%$. Bachelor's degree with frequency of $61 \%$ and diploma education and lower, with frequency of $4 \%$, shows the highest and the lowest frequency, respectively. Regarding work experience, the highest frequency is related to 21 to 25 years work experience with frequency of $36 \%$, and the lowest frequency belongs to work experience of 26 years and higher, with frequency of $3 \%$. According to the statistics, male worker number with frequency of $57 \%$ was more than the number of female employees.

Table 1: Demographic characteristics

\begin{tabular}{|c|c|c|c|c|c|c|c|c|c|c|c|}
\hline Age of staff & No. & F. & education & No. & F. & $\begin{array}{l}\text { work } \\
\text { experienc } \\
\text { e }\end{array}$ & No. & F. & Sex & No. & F. \\
\hline Up to 25 years old & 9 & $3 \%$ & $\begin{array}{l}\text { Diploma and } \\
\text { lower }\end{array}$ & 12 & $4 \%$ & $\begin{array}{l}\text { Up to } 5 \\
\text { years }\end{array}$ & 23 & $8 \%$ & $\begin{array}{l}\text { Femal } \\
\mathrm{e}\end{array}$ & 122 & $\begin{array}{l}43 \\
\%\end{array}$ \\
\hline 25 to 35 years old & 51 & $18 \%$ & $\begin{array}{l}\text { Associate } \\
\text { Degree }\end{array}$ & 45 & $16 \%$ & $\begin{array}{l}6 \text { to } 10 \\
\text { years }\end{array}$ & 37 & $13 \%$ & Male & 163 & $\begin{array}{l}57 \\
\%\end{array}$ \\
\hline 36 to 45 years old & 58 & $20 \%$ & Bachelor & 175 & $61 \%$ & $\begin{array}{l}11 \text { to } 15 \\
\text { years }\end{array}$ & 42 & $15 \%$ & & & \\
\hline 46 to 55 years old & 154 & $54 \%$ & $\begin{array}{l}\text { Master's degree } \\
\text { and higher }\end{array}$ & 53 & $19 \%$ & $\begin{array}{l}16 \text { to } 20 \\
\text { years }\end{array}$ & 71 & $25 \%$ & & & \\
\hline $\begin{array}{l}56 \text { years old and } \\
\text { higher }\end{array}$ & 13 & $5 \%$ & - & - & - & $\begin{array}{l}21 \text { to } 25 \\
\text { years }\end{array}$ & 103 & $36 \%$ & & & \\
\hline $\begin{array}{l}56 \text { years old and } \\
\text { higher }\end{array}$ & 0 & 0 & - & - & - & $\begin{array}{l}26 \text { years } \\
\text { and higher }\end{array}$ & 9 & $3 \%$ & & & \\
\hline Total & 285 & $\begin{array}{l}100 \\
\%\end{array}$ & & 285 & $\begin{array}{l}100 \\
\%\end{array}$ & & 285 & $\begin{array}{l}100 \\
\%\end{array}$ & & 285 & $\begin{array}{l}100 \\
\%\end{array}$ \\
\hline
\end{tabular}




\section{2 inferential statistics}

In inferential statistics section, by using structural equation modeling and path analysis coefficients, the effect of work plateau on intention to remain in organization with mediating role of organizational commitment of employees is discussed. The structural equation model in this study is determined using LISREL software.

\subsection{Research hypotheses tests}

To examine the relationship between variables and test the hyopthses, the path analysis coefficients or Structural
Equation Model is used. Research data have been analyzed by Lizrel software. The statistical tests results of hypotheses are discussed in the following manner.

\subsubsection{Chart of path coefficients in standard estimation mode}

This chart shows the relationship between latent and observed variables in one model. In the chart below, research path coefficients are shown. The numbers on the arrows represent the path coefficients of the variables that are obtained using LISREL software. Ovals represent variables and rectangles represent questions of variables.

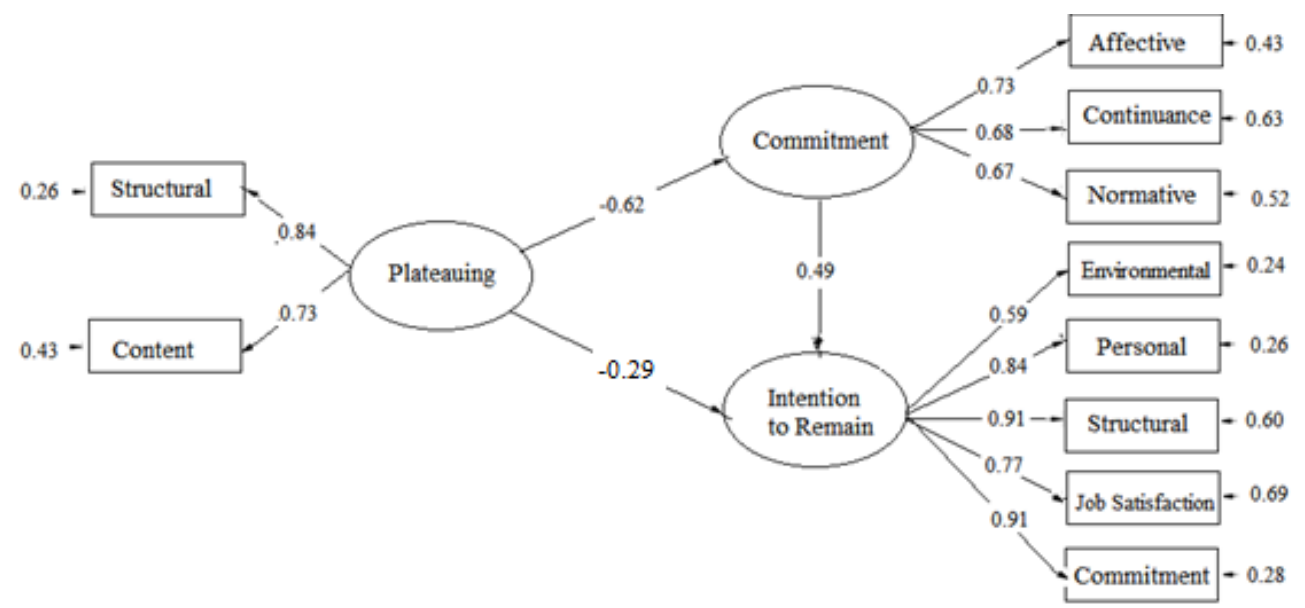

Figure No. 6: Structural Equation Modeling Results (Standard Estimation) of the Studied Variables

7.3.2 Chart of $\mathbf{T}$ value for each of the path coefficients in $\mathrm{T}$ value is outside the range of (-1.96 and 1.96), obtained significant state

The following chart shows the value of test statistics for each relationship will be meaningful with more than $95 \%$ coefficient. Here, for each parameter in the model, an observed $\mathrm{T}$ value is obtained, and it can be interpreted that if the observed

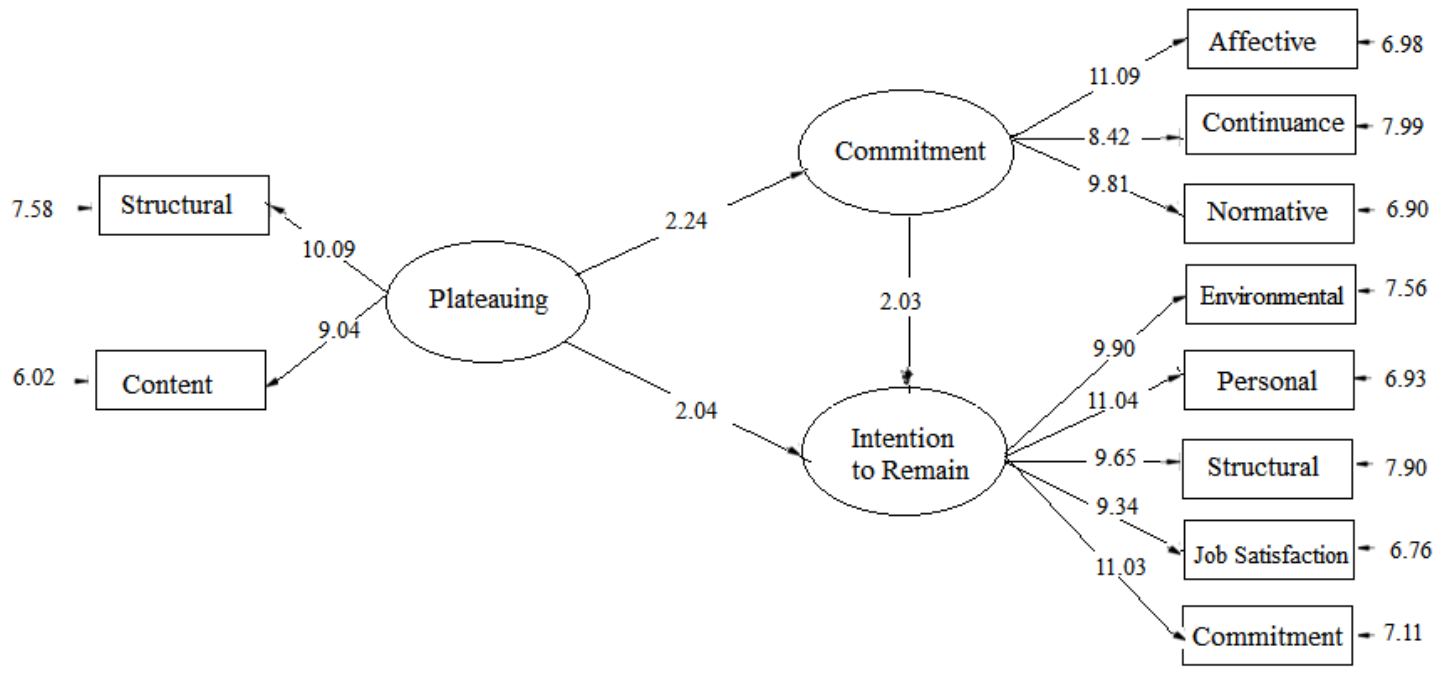

Figure No. 7: T value for each path coefficient

\subsubsection{Fitness of proposed research model}

In order to evaluate the model fitness, model indexes should have the required standards. So, in the next step, fitness of the model with the data collected by the researcher should be examined, hence some of goodness of fit tests are conducted for used model and research data to evaluate the fitness. As shown in Table 1 , if fitness index of $\mathrm{x} 2 / \mathrm{df}$ is less than 3 , RMSEA value is less than 0.08 , and the fitness index of GFI, AGFI, NFI, NNFI, and CFI are greater than 0.09, these figures indicate that the proposed model is confirmed and the model has good fitness. 
Table II: Value of fitness indexes and fitness result of structural model

\begin{tabular}{|l|l|l|l|l|}
\hline No. & Good of fitness Index & Acceptable Value & Model Value & Good of fitness Results \\
\hline 1 & df & More than zero & 819 & Acceptable \\
\hline 2 & x2/ df & Less than 3 is suitable & 2.21 & Acceptable \\
\hline 3 & RMSEA & Less than 0.08 is suitable & 0.071 & Acceptable \\
\hline 4 & NNFI & More than 0.9 & 0.92 & Acceptable \\
\hline 5 & CFI & More than 0.9 & 0.91 & Acceptable \\
\hline 6 & GFI & More than 0.9 & 0.90 & Acceptable \\
\hline 7 & NFI & More than 0.9 & 0.96 & Acceptable \\
\hline 8 & AGFI & More than 0.9 & 0.93 & Acceptable \\
\hline
\end{tabular}

\section{RESEARCH FINDINGS}

According to the results of collected data analysis, the results of research hypotheses test based on T-value are presented in Table 2. It should be noted that relationships in which the values of statistics are outside the range of (-1.96 and 1.96) are confirmed. Therefore, all three paths that exist between independent latent variables and dependent latent variables are significant.

Table III: The Results of research hypotheses test

\begin{tabular}{|l|l|l|l|l|}
\hline Hypotheses & $\begin{array}{l}\text { Path } \\
\text { coefficient }\end{array}$ & $\begin{array}{l}\text { T } \\
\text { value }\end{array}$ & $\begin{array}{l}\text { Comparison with } \\
\text { critical values }\end{array}$ & $\begin{array}{l}\text { Rejected/ } \\
\text { Accepted }\end{array}$ \\
\hline $\begin{array}{l}\text { 1. Work plateau has a negative impact on the intention } \\
\text { of employees to remain in organization }\end{array}$ & $0.29-$ & 2.04 & $1.96>2.04$ & Accepted \\
\hline $\begin{array}{l}\text { 2. Work plateau has a negative impact on } \\
\text { organizational commitment }\end{array}$ & $0.62-$ & 2.24 & $1.96>2.24$ & Accepted \\
\hline $\begin{array}{l}\text { 3. Organizational commitment has a positive impact } \\
\text { on employees' intention to remain in organization }\end{array}$ & 0.49 & 2.03 & $1.96>2.03$ & Accepted \\
\hline
\end{tabular}

be said that organizational commitment has a positive effect on intention to remain in organization and for one unit

As shown in Table 3 and Figure 6, work plateau has a negative and significant effect on intention to remain in organization (first hypothesis of the research), according to which the value of path coefficient between work plateau and intention to remain in organization is -.029 and coefficient $\mathrm{T}$ value is $1.96<2.04$, which is significant at level of 0.05 . So first hypothesis is confirmed and by $95 \%$ confidence, it can be said that work plateau has a negative effect on intention to remain in organization and for one unit of increase in work plateau, intention to remain in organization decrease by 0.29 units.

According to the second hypothesis, work plateau has a negative effect on organizational commitment. According to the results of data analysis, the value of path coefficient between work plateau and organizational commitment is -0.62 and $\mathrm{T}$ value for this coefficient is $1.96<2.24$, which is significant at the level of 0.05 . So the researcher's claim is approved and by $99 \%$ confidence, it can be said that work plateau has a positive effect on organizational commitment and for one unit of increase in organizational learning, organizational commitment decreases by 0.62 units.

According to the third hypothesis of research, the effect of organizational commitment on intention to remain in organization is positive and significant. According to the results of data analysis, the value of path coefficient between the organizational commitment and intention to remain in organization is 0.49 and $\mathrm{T}$ value for this coefficient is 1.96 $<2.10$, which is significant at the level of 0.05 . Therefore, the researcher's claim is confirmed and by $95 \%$ confidence it can increase in organizational commitment, intention to remain in organization increases by 0.49 units.

The causal paths coefficients between three variables of the research show the direct and indirect effect (through mediator variable of organizational commitment) of work plateau on intention of the employees to remain in organization. The direct effect was -0.29 , indirect effect was $-0.30(-0.62 * 0.49)$ and the total effect was $-0.59(-0.29+-0.30)$.

\section{CONCLUSION AND RECOMMENDATIONS}

Research shows that in the next decade, work plateau will be one of the most important challenges for human resources in organizations (Jung and Talk, 2008). Even some have claimed that roughly $80 \%$ of the tasks and occupations carried out by organizations are carried out by workers who have experienced work plateau (Ongori and Angolla, 2009). it is clear that addressing this issue in organizations is important and necessary, because neglectingwork plateau will reduce job satisfaction, performance and commitment, and increase the intention to leave the job (Ongori and Angolla, 2009; Heilmann, Hot and Rilovick, 2008; Klehe, Zikic, Van De Pater, 2011). In this research, the first hypothesis examines the relationship between job plateau on the desire to remain in the organization. The results showed a negative and significant relationship between job plateau on the desire to remain in organization, which is consistent with the research of Lee and others (1999), Ongori and Angolla (2009) and Lentz and Allen (2008). It 
was concluded that there is a positive relationship between work plateau and intention to leave the organization and is consistent with Rotondo \& Perewe (2000), which refered to the negative relationship between work plateau and the intention to remain in organization. Therefore, it is recommended to avoid doing routine job for a long time and to provide employees with the opportunity to upgrade and improve their skills through career planning and designing training courses. In addition, improving the status of occupational safety, empowerment, and welfare facilities will also support employees' adherence to origination and reduce their desire to leave the job.

Herzberg has also proposed two important mechanisms called job development and job enrichment (development of occupational responsibilities), which can be one of the best solutions to overcome the work plateau. (Hersey, Blanchard, 2011)

The second hypothesis examines the relationship between work plateau and organizational commitment. The results showed a negative and a significant relationship between job plateau and organizational commitment, which is consistent with McCleese and others (2007), Drucker et al. (2014), Jang and Tak (2008), Lentz and Allen (2009), McLeans \& Eby (2006), which showed that work plateau and lack of progress in the organization reduces organizational commitment of employees. So our recommendation is to provide programs such as job rotation and mobility and environmental diversification. According to Imel, job rotation simply means changing job within the organization or essentially changing career paths and even going a different way (Imel, 2001) that is as below

- Ascending movement: i.e. searching a position with more responsibility

- Horizontal movement: that occurs in the organization and with peer posts, especially for those who consider their job as dull and boring (Harris, 1993, p4), some such as Bardwick suggest that the horizontal displacement of staff should happen at least every five years (Lioyod, 1986, p15)

- Downward movement: Job change and lower liability, especially for those who are more likely to be faced with issues such as family problems, organizational matters, leisure, sickness, or involved with higher social commitments (Dahle, 1998, p11).

The third hypothesis examines the relationship between organizational commitment and desire to remain in organization. The results showed a positive correlation between the organizational commitment and the desire to remain in organization, which was consistent with Balfour and Wechsler (1986) and Stup (2006), which all in their research showed that among the organizational commitment has a positive and significant relationship with desire to remain in organization.

Therefore, top managers should demonstrate appropriate, principled, correct and respectful attitudes towards employees, and create a sense in all employees that their partnerships and creativity are honored and respected in the organization, so that employees are more concerned about the organization, because if employees feel that managers disregard their suggestions, they will reduce their membership and dependence on the organization.

In addition, creating a friendly environment with the provision of a happy working environment and an attractive organizational atmosphere combined with joy and happiness will attract the employees to workplace.

This condition will make the employee feel that if in long run he leaves the organization, he will lose a lot of positive conditions.

In addition, the use of mechanisms such as fair payment, respect for justice in the distribution of rewards, autonomy in working and strengthening the team spirit in the organization can strengthen the attitude of organizational commitment.

\section{REFERENCES}

1. Allen, N. g. And J. P. Meyer, 1990. The measurement and antecedents of affective, continuance and normative commitment to the organization. J. Occup. Psychol., 63:1-18

2. Armstrong-Stassen, M., \& Stassen, K. (2013). Professional development, target-specific satisfaction, and older nurse retention. Career Development International, 18(7), 673-693.

3. Balay, R., 2000. Organizational Commitment of Administrators and Teachers. Nobel Publishing Ankara.

4. Balfour, D., \& Wechsler, B. (1996). Organizational commitment: Antecedents and outcomes in public organizations. Public Productivity \& Management Review, 19 (3), 256-277.

5. Baoguo, X. (2015). Does Double Plateau Always Lead to Turnover Intention?, Journal of Career Development, 11(2), pp. 321-332.

6. Barwick, J. M. (1986). The plateauing trap. New York: Amacom

7. Barwick, J.M. (1986). The plateauing trap. Toronto: Bantam Books.

8. Bhatnagar,s,J.(2005). The power of psychological epowermant as an antecedent to organizational commitment in indian manager Mdi.419.

9. Bluedorn, A.C. (1982). A Unified model of turnover from organizations. Human Relations, 35(2).135-153.

10. Career Development, 11(2), pp. 321-332.

11. Cheng,Y. and \& Stockdale, M.S., 2003. The validity of the threecomponent model of rganizational commitment in a Chinese context.Journal of Vocational Behavior.

12. Choudhary, A. S., Ramzan, M.,\& Riaz, A. (2013). Strategies for career plateau: Empirical investigation of organizations in Pakistan. Interdisciplinary Journal of Contemporary Research In Business, 4, (9), 712-726.

13. Conner, D. (2014). The effects of career plateaued workers on in-group members' perceptions of P-O fit. Employee Relations, 36(2), 198-212.

14. Currivan. D, B. (2000). The causal order of job satisfaction and organizational commitment in models of employee turnover. Human Resource Management Review. 9, 495-524.

15. Delgoshayi, Bahram et al. (2008). "Relationship Between Organizational Climate and Organizational Commitment of Staff and Managers of Educational Hospitals of Hamedan University of Medical Sciences. Afqn Danesh Journal, Volume 14, Issue 4, pp. 69

16. Drucker-Godard, C., \& Fouque, T., Gollety, M., \& Le Flanchec, A (2014). Career plateauing, job satisfaction and commitment of scholars in French universities. Public Organization Review, Published online: 9 April.

17. Egan, T. M., Yang, B., \& Bartlett, K. (2004). The effects of organizational learning culture and job satisfaction on motivation to transfer learning and turnover intention. Human Resource Development Quarterly, 15, 279-301.

18. Evans, L (1998). Teacher, Morale, jab satisfaction and motivation. Thousand oaks.

19. Fayyazi, Marjan \& Ziaee Soraya, (2014). The Effect of Career Plateau on Job Burnout and Desire to leave in Librarians, Journal of Management and Development, Year 6, Issue 11, 73-91

20. Foster P. B.; Shastri, T., \& Withane, S. (2004). The Impact of mentoring on career plateau and turnover intentions of management accountants. Journal of Applied Business Research, 20(4), 33-42.

21. Gaffney, S. (2005). "Career development as a retention and succession planning tool". The Journal for Quality \& Participation. 28(3), 7-10.

22. Gholipour, R. and et el (2003), Identification of factors affecting sustainability of knowledge workers in Iran Oil Refining and Distribution Company. Journal of rganizational Culture Management, Volume 11, Number 2, summer 2013, pp. 133-161. 
23. Griffeth, R. W., Steel, R. P., Allen, D. G., \& Bryan, N. (2005). The development of a multidimensional measure of job market cognitions: The Employment Opportunity Index (EOI). Journal of Applied Psychology, 90(2), 335-349. doi:10.1037/0021-9010.90.2.335

24. Griffin, Moorhead (1998), Organizational Behavior, Translated by Seyyed Mahdi Alvani and Gholamreza Memarzadeh, Third Edition, Tehran: Morvarid.

25. Haj Karimi, A, Tabarsa, Gh. Rahimi, F, 2008. Investigating the Impact of Human Resource Actions on Organizational Citizenship Behaviors Considering the Role of Organizational Commitment. Andisheh Journal. Management, second year, No. 11.

26. Harris, Wayne (1995) clocked out. A change American workplace means pain for survivors on both sides of the desk mailer. Fsu.Edu/

27. Heilmann, S. G., Holt, D. T., \& Rilovick, C. Y. (2008). Effects of Career Plateauing on Turnover: A Test of a Model. Journal of Leadership and Organizational Studies. 15, 59-68.

28. Hersey Powell, Blanchard Kent (2011), Organizational Behavior Management, Human Resource, Translated by Qasem Kabiri , Amir Kabir Publications. 64.60.

29. Hornaday, Ann (1995), how do you know when it is time to go? http// www.fastcompany.com

30. Hurst, S. C., Kungu, K., \& Flott, P. (2012). Stress, organizationa citizenship behaviors, and coping: Comparisons among plateaued and non-plateaued employees. Business and Management Research, 1(3), 17-27.

31. Imel, Susan, (2001). "Surviving the career doldrums". ICDL. Uncg. $\mathrm{Edu} / \mathrm{ft} / \mathrm{html}$

32. Jung, J., \& Tak, J. (2008). The effects of perceived career plateau on employees' attitudes moderating effects of career motivation and perceived supervisor support with Korean employees. Journal of Career Development, 35(2), 187-201.

33. Kantar, DS (1980). Personnel: The management of people at work McMillan.

34. Ketchum, L. D. \& Trist, E. (1992). All Teams Are Not Created Equal. How Employee Empowerment Really Works. Newbury Park, Sage.

35. Khanifar, Hossein (2006). Investigating the Psychological Dimensions of Job Plateauing and Providing Practical Outputs, 111- Management Culture, p. 12 , p. 5

36. Klehe, U., Zikic, J., Van Vianen, A.E.M., and De Pater, I.E. (2011) Career adaptability, turnover, and loyalty during organizational downsizing. Journal of Vocational Behavior, 79, 217-229.

37. Kline, R. B. (2010). Principles and practice of structural equation modeling (3th Ed.). New York: Guilford Press

38. Kolahchiyan, M., Rahmati Niya, R. (2017). Explaining the phenomenon of Career Plateauing in employees of security agencies. Quarterly Journal of Security Researches of Imam Hossein University (AS) 55, Year 6, Number 2, Number 22 (Summer 2017), 90

39. Kuvaas, B. (2003). Employee ownership \& affective organizationa ommitment: Employees' perceptions of fairness \& their preference for company shares over cash. Scandinavian Journal of management.

40. Lee, P. C. B. (1999). Career plateau and professional plateau: Impact on work outcomes of informational technology professionals. ACM SIGCPR Computer Personnel, 20(4), 25-38.

41. Lee, P. C. B. (2003). Going beyond career plateau: using professional plateau to account for work outcomes. Journal Management Development, 22(6), 538-551.

42. Lentz, E., \& Allen, T. D. (2009). The Role of Mentoring Others in the Career Plateauing Phenomenon. Group \& Organization Management, 34(3), 358-384.

43. Mafi P. [Relationship between Organizational Commitment and intention to remain at Job of occupational personnel of Organization for Investment, Economic \&Technical Assistance of Iran].

44. McCleese, C. S., \& Eby, L. T. (2006). Reactions to job content plateaus: Examining role ambiguity and hierarchical plateaus as moderators. The Career Development Quarterly, 55, 64-76.

45. McCleese, C. S., Eby, L. T., Scharlau, E. A., \& Hoffman, B. H. (2007) Hierarchical, job content, and double plateaus: A mixed method study of stress, depression and coping responses. Journal of Vocational Behavior, 71, 282-299.

46. Meyer, J. P., \& Allen, N. J. (1990). A three-component conceptualization of organizational commitment. Human Resource Management Review, 1 (1), 61-89.

47. Meyer, J. p., Allen, N.j. \& Smith, C.A. (1993). Commitment to organizations and occupations: extension and test of a three-component model. Journal of Applied Psychology, 78: 538-551.

48. Meyer JP, Stanly D J,Herscovich L, Topolnytsky L. (2002). Affective, Continuance, and Normative Commitment to the Organization: A meta analysis of antecedents, correlates and consequences. JVocat Behav. 2002;61:20-52.

49. Miles, S.; Gordon, J., \& Storlie, C. (2013). Job satisfaction, perceived career plateau, and the perception of promotability: a correlational study. The Journal of International Management Studies, 8(1), 1-9.

50. Moghimi, Seyed Mohammad. (1996). Organization and Management, terme publisher, pp. 403-390.

51. Molayi, Nasser (2006), Professionalism and Staff Commitment, Ph.D. Thesis., Tehran: Allameh Tabatabaei University.

52. Nachbagauer, A. G. M., \& Riedl, G. (2002). Effects of concepts of career plateaus on performance, work satisfaction and commitment. International Journal of Manpower, 23(8), 716-733.

53. Ongori, H. and Angolla, J.E. (2009). Paradigm shift in managing career plateau in organization: the best strategy to minimize employee intention to quit. African journal of business management, 3(6), 268-271

54. O'Reilly, C \& chatment, J 1986, 'Organizational commitment and Psychological attachment. The effects of compliance, identification and internalization on prosocial behavior', Journal of Applied Psychology, Vol. 71, no.2.

55. Penkar D J \&Agrawal, R K. (2012), A Study of Employees Career Plateau in Education Sector With Reference To Pune City, International Journal of Business and Management Tomorrow.2012;2 (3):1-9.

56. Poorkiyani, M., \& Zamani Fard, M., 2008. Organizational commitment is a reflection of organizational justice. Industry and Entrepreneurship Monthly

57. Powell D M, Meyer J P (2004), Side-bet theory and the three-component model of organizational commitment, J Vocat Behav.2004,65:157-177.

58. Price, J.L., and Muller, C.W. (1981). A Causal model of Turnover for nurses, Academy of Management Journal, 24(3), 543-565

59. Robbins Stephen. Organizational behavior management. Translated by: Ali Parsaeian and

60. Mohammad Aerabi. 1st ed. Tehran: published in commercial studies and researches institute 1994: 265.

61. Rotondo, D. \& Perewe, P. L. (2000). Coping with a Career Plateau: An Empirical Examination of What Works and What Doesn't. Journal ofApplied Social Psychology, 30(3), pp. 2622-2646.

62. Salami, O. S. (2010). Career plateauing and work attitudes: Moderating effects of mentoring others with Nigerian employees. Europe's Journal of Psychology,6, (4), 71-92.

63. Saleh Ardestani, Abbas \& Mir Ali, Seyed-Naghavi (2016). Explaining the Relationship between Employees Job Plateau, Organizational Indifference and Desire to Quit, Public Management Research, Vol. 9 , No. 31, 145-160

64. Sharifian, E., Pirayesh, M.,\& Rahimi, G. (2013). Relationship between work positive attitudes and employees, vocational plateau of offices of sport and youth in Kerman Province of Iran. National Park-forschungin der schweiz, 102, (10), 986-997.

65. Simons E S. predictors of organizational commitment among staff in assisted living,Genotolog.2005,45(2):196-205

66. Stamps, P. L (1997). Nurses and work satisfaction: and Index for Measurement.

67. Stup, R .(2006). Human resource management and Dairy employee organizational commitment. The Pennsylvania state university.

68. Tabarsa, Gh.,et al (2014). Designing and explaining the management pattern of career plateauing in Iranian organizations (Case study of Ministry of Industry, Mine and Trade), Quarterly of Management of Government Organizations, Volume 3, Issue 1, 90-103

69. Taleghani, J., \& Mottaghi M. (2002), investigating the relationship between behavioral styles which are exposed to static phenomenon in the path of career progression and employee performance in the National Copper Industries Company of Iran (Sarcheshmeh Copper Complex), Thesis of Islamic Azad University of Kerman 